\title{
SOSIALISASI DAN PENGENALAN KEUANGAN DAN PERBANKAN SYARIAH PADA SISWA TINGKAT AKHIR
}

\author{
Anna Sardiana, Alvien Nur Amalia, Puspita* \\ Program Studi Manajemen Keuangan dan Perbankan Syariah \\ STIE Indonesia Banking School
}

\begin{abstract}
ABSTRAK
Survei Otoritas Jasa Keuangan memperlihatkan bahwa hanya $21,84 \%$ penduduk Indonesia yang tergolong well literate. Hal ini menunjukkan rendahnya tingkat literasi keuangan masyarakat Indonesia. Salah satu segmen masyarakat yang dapat dikatakan belum banyak mendapat perhatian pada industry keuangan khususnya keuangan syariah, adalah kelompok usia muda yang dalam kategori menjelang usia produktif yaitu remaja, khususnya siswa sekolah menengah tingkat akhir. Hal ini berkenaan dengan asumsi bahwa ketika segmen siswa ini telah bekerja, mereka cenderung berpenghasilan, dan berpotensi untuk menjadi pengguna jasa keuangan, sehingga perlu mendapat edukasi. Madrasah Aliyah Negeri (MAN 18) Jakarta, Pondok Pesantren Baitul Hidayah Bandung, dan Sekolah Menengah Atas Negeri (SMAN 68) Jakarta merupakan beberapa sekolah yang mewakili representasi siswa tingkat akhir di kota besar Indonesia. Sehingga perlu dilakukan workshop dalam bentuk sosialisasi dan pengenalan keuangan dan perbankan syariah kepada para siswa disekolah-sekolah ini yang pada akhirnya diharapkan memberi dampak pada pertumbuhan industry keuangan Syariah dimasa yang akan datang.
\end{abstract}

Kata Kunci : Literasi Keuangan, Keuangan Syariah, Perbankan Syariah

\begin{abstract}
According to The Financial Services Authority's survey, shows that only $21.84 \%$ of the Indonesian population is well literate. This shows that level of Indonesian society financial literacy are stay at the low level. One segment of society that can be said has not received much attention in the financial industry, especially Islamic finance, is a young age group in the category of 'will be next productive age of adolescents', especially at the end level of high school students. Due to the assumption that when this segment has worked, they are likely will be potential to become financial services users, thus need to get an Islamic finance knowledge. Last year students of Madrasah Aliyah Negeri (MAN 18) Jakarta, Pondok Pesantren Baitul Hidayah Bandung, and State Senior High School (SMAN 68) Jakarta are some schools that represent students of some big cities in Indonesia. So it is necessary to conduct workshops in the form of socialization and introduction of Islamic finance and banking to the students in these schools which ultimately are expected to impact on the growth of the Islamic financial industry in the future.
\end{abstract}

Keyword : Financial Literacy, Islamic Finance, Islamic Banking 


\section{Pendahuluan}

$\begin{array}{ccr}\text { Survei } & \text { Bank } & \text { Indonesia } \\ \text { menyebutkan } & \text { tingkat } & \text { literasi }\end{array}$ keuangan masyarakat Indonesia sangat rendah. Sejalan dengan hal itu, Otoritas Jasa Keuangan juga menemukan, dibandingkan negara tetangga, tingkat literasi yang cukup baik di Indonesia hanya 20 persen. Hal ini jauh berbeda dari Filipina yang mencapai 27 persen, Malaysia 37 persen, Singapura 98 persen. (OJK, 2013)

Dari sisi indeks utilitas produk dan jasa keuangan yang merupakan parameter atau indikator untuk mengukur seberapa banyak masyarakat Indonesia memanfaatkan produk jasa keuangan, survei menunjukkan $59,74 \%$ tingkat penggunaan jasa keuangan. Namun demikian, utilitas produk dan jasa keuangan ini tidak merata disetiap sektor jasa keuangan.

Berdasarkan survei Otoritas Jasa Keuangan, terlihat bahwa tidak semua masyarakat dapat memanfaatkan produk dan layanan jasa keuangan. Hal ini disebabkan karena masyarakat masih memiliki persepsi sulitnya memenuhi persyaratan dalam memperoleh produk dan jasa keuangan, belum memahami fungsi dan manfaat produk dan jasa keuangan yang disebabkan edukasi yang kurang memadai, belum mampu menjangkau beberapa produk dan jasa keuangan serta mengalami kesulitan dalam mengakses produk dan jasa keuangan yang disebabkan keterbatasan sarana dan prasarana.

Hasil survei Otoritas Jasa Keuangan yang dituangkan dalam indeks literasi keuangan merupakan parameter atau indikator yang menunjukkan tingkat pengetahuan, keterampilan dan keyakinan masyarakat terkait lembaga keuangan serta produk dan jasanya. Berdasarkan indikator tersebut, dari 8000 responden survei, diketahui bahwa hanya $21,84 \%$ penduduk Indonesia yang tergolong well literate (OJK, 2013). Hal ini menunjukkan rendahnya tingkat literasi keuangan masyarakat Indonesia. Pada aspek pertumbuhan penduduk, populasi masyarakat muslim menurut data dari Sensus penduduk yang dilakukan oleh Badan Pusat Statistik tahun 2010 menunjukkan bahwa sebesar $87 \%$ atau 207.761.162 jiwa dari 237.641.326 jiwa penduduk Indonesia beragama Islam. Dari jumlah populasi tersebut, 150 juta orang disebutkan memiliki peluang untuk mengakses produk dan jasa keuangan, khususnya jasa keuangan syariah. Namun kenyataannya baru 2 persen yang terpenuhi. Hal ini terlihat pada market share perbankan syariah yang masih dikisaran 5 persen dari total aset perbankan di Indonesia sebagai salah satu lembaga jasa keuangan yang dominan dibanding lembaga jasa keuangan lainnya di Indonesia.

\subsection{Analisis Situasi}

Salah satu segmen masyarakat yang menjanjikan dan dapat dikatakan belum banyak mendapat perhatian pada industry keuangan khususnya keuangan syariah, adalah kelompok usia muda yang dalam kategori menjelang usia produktif yaitu remaja, khususnya siswa sekolah menengah tingkat akhir. Dengan asumsi bahwa ketika segmen siswa ini telah bekerja, mereka cenderung berpenghasilan, dan berpotensi untuk menjadi pengguna jasa keuangan. Hal ini sejalan dengan potensi bonus demografi Indonesia pada usia produktif ditahun 2030 . 
Dengan demikian, perlu adanya pengenalan dan pemahaman dikalangan siswa mengenai keuangan Syariah secara umum dan perbankan Syariah secara khusus dalam rangka meningkatkan tingkat literasi keuangan secara umum dan literasi keuangan Syariah secara khusus.

Madrasah Aliyah Negeri (MAN 18) Jakarta, Pondok Pesantren Baitul Hidayah Bandung, dan Sekolah Menengah Atas Negeri (SMAN 68) Jakarta merupakan beberapa sekolah yang mewakili representasi siswa tingkat akhir di kota besar Indonesia dengan literasi keuangan Syariah yang minim. Sehingga perlu dilakukan workshop dalam bentuk sosialisasi dan pengenalan keuangan dan perbankan syariah kepada para siswa disekolah-sekolah ini yang pada akhirnya diharapkan memberi dampak pada pertumbuhan industry keuangan Syariah dimasa yang akan datang.

\subsection{Permasalahan Mitra}

Tingkat literasi keuangan masyarakat Indonesia yang rendah merupakan representasi dari kondisi industry keuangan di Indonesia dimana keuangan Syariah menjadi salah satu komponen dari industry tersebut. Sehingga rendahnya pengetahuan dan pemahaman siswa terkait jasa keuangan dan perbankan Syariah turut andil dalam perkembangan industry keuangan syariah.

\section{Metode Pelaksanaan}

Metode kegiatan ini berupa sosialisasi dan pengenalan tentang jasa keuangan Syariah dan perbankan Syariah kepada para siswa yang didampingi oleh para guru di masing-masing sekolah. Setelah sosialisasi dan pengenalan, para siswa diberi pengetahuan mengenai dasar-dasar ekonomi Islam, implementasi ekonomi Islam dalam kehidupan sehari-hari serta penerapannya pada jasa keuangan Syariah.

Adapun tahapan yang dilakukan dalam kegiatan pengabdian pada masyarakat ini adalah :

1. Tahap Persiapan

Tahap persiapan yang dilakukan meliputi: a. survei lokasi; b. Pemantapan dan penentuan lokasi dan sasaran, penyusunan bahan atau materi sosialisasi serta penunjang lainnya seperti surat menyurat, spanduk, daftar hadir, sertifikat, konsumsi, transportasi dan lain-lain.

2. Tahap Pelaksanaan.

Pelaksanaan kegiatan diawali dengan seremonial pembukaan dan sambutan yang berkenaan dengan tujuan pelaksanaan kegiatan yaitu peningkatan literasi keuangan Syariah para siswa sehingga diharapkan kelak akan berkontribusi pada perkembangan industry keuangan Syariah.

Adapun metode sosialisasi dan pengenalan keuangan dan perbankan syariah yang dilakukan adalah sebagai berikut :

a. Metode ceramah interaktif antara pemateri dan para siswa, dimana penyampaian materi menggunakan pendekatan student centerd learning sehingga siswa tidak 
bosan dengan materi yang disampaikan.

b. Metode tanya jawab dimana para siswa diberi kebebasan dalam memenuhi rasa ingin tahu melalui tanya jawab yang waktunya tidak ditentukan. Sehingga kapan pun para siswa ingin bertanya, mereka diperkenankan untuk bertanya meskipun materi belum selesai.

c. Metode simulasi yang dilakukan secara sederhana dalam praktek berekonomi sehari-hari misalnya jual beli, sewa menyewa, kerjasama dan lain-lain dalam konteks ekonomi syariah.

\section{Hasil dan Pembahasan}

Kegiatan Pengabdian pada masyarakat yang dilakukan tim dosen program studi manajemen keuangan dan perbankan Syariah ini dapat dilihat dalam bentuk hasil kegiatan pada setiap pelaksanaan kegiatan yang terdiri dalam beberapa tahap, yaitu: perencanaan, tindakan, observasi, evaluasi dan refleksi. Adapun rincian hasil kegiatan dapat dilihat pada uraian berikut :

\section{a. Perencanaan}

Kegiatan kegiatan yang dilakukan pada tahap perencanaan adalah:
1. Merancang mekanisme program pengabdian pada masayarakat

2. Rapat koordinasi dengan Kepala
Sekolah dan guru di setiap sekolah yaitu MAN 18 Jakarta, Pondok Pesantren Baitul Hidayah Bandung dan SMAN 68 Jakarta yang dilakukan oleh Tim pengabdian masyarakat

3. Menyusun dan menyiapkan materi yang akan di sampaikan pada pelaksanaan pengabdian masyarakat di MAN 18 Jakarta, Pondok Pesantren Baitul Hidayah bandung dan SMAN 68 Jakarta

4. Menyusun teknis yang berkaitan dengan metode atau teknik pelaksanaan pengabdian masyarakat di setiap sekolah (MAN 18 Jakarta, Pondok Pesantren Baitul Hidayah Bandung dan SMAN 68 Jakarta)

\section{b. Tindakan}

Kegiatan pengabdian pada masyarakat ini dilakukan sebagai upaya meningkatkan literasi keuangan syariah para siswa menengah akhir melalui pendekatan sosialisasi dan pengenalan keuangan dan perbankan syariah. Kegiatan disetiap sekolah dilaksanakan pada waktu yang berbeda yaitu, MAN 18 dilaksanakan pada tanggal 15 Februari 2018 dengan jumlah peserta sebanyak 45 peserta; Pondok Pesantren Baitul Hidayah Bandung dilaksanakan pada tanggal $3-4$ April 2017 dengan jumlah peserta 
sebanyak 32 peserta dan SMAN 68 dilaksanakan pada tanggal $2-5$ April 2018 dengan jumlah peserta sebanyak 35 peserta.

\section{Observasi}

Observasi dilakukan terhadap para siswa sebelum dan setelah kegiatan dilaksanakan. Hal ini dilakukan untuk mengetahui tingkat pengetahuan dan pemahaman sebagai salah satu indicator literasi keuangan. Sehingga upaya edukasi dalam rangka meningkatkan pengetahuan dan pemahaman yang berkenaan dengan keuangan dan perbankan Syariah dapat tercapai.

Beberapa hal yang di observasi adalah kendala -kendala yang muncul dalam proses workshop dalam bentuk sosialisasi. Kendala yang terjadi seperti kurangnya efektivitas waktu yang digunakan selama proses workshop berlansung. Namun demikian, terdapat beberapa kelebihan dari pelatihan ini diantaranya, para siswa disekolah dengan latar belakang agama seperti MAN 18 dan Pondok Pesantren Baitul Hidayah, telah memiliki basic agama yaitu prinsip-prinsip dasar berekonomi dalam Islam sehingga lebih mudah untuk memahami materi yang disampaikan. Adapun SMAN 68 memiliki pengetahuan umum yang lebih luas, sehingga lebih mudah untuk memahami kondisi perekonomian secara umum.

\section{c. Evaluasi}

Berdasarkan observasi diatas, untuk mengatasi kendala yang terjadi pada proses workshop, perlu dilakukan evaluasi efektivitas waktu sosialisasi dan pengenalan keuangan dan perbankan Syariah. Evaluasi ini bertujuan agar dapat mengatasi kendala waktu tersebut pada kegiatan workshop sosialisasi dan pengenalan keuangan dan perbankan Syariah berikutnya.

\section{d. Refleksi}

Untuk mencapai tingkat literasi keuangan Syariah para siswa sekolah menengah tingkat akhir ini menjadi well-literate, edukasi keuangan dan perbankan Syariah harus dilakukan secara berkesinambungan. Untuk itu, perlu dibuat tahapan-tahapan dalam merumuskan materi mulai materi dasar yang berkenaan dengan ekonomi Islam secara umum hingga materi spesifik yang berkenaan dengan keuangan dan perbankan Syariah, yang akan disampaikan kepada para siswa secara bertahap. Sehingga hal ini dapat mengatasi masalah efektivitas waktu yang tidak maksimal.

\section{e. Pembahasan}

Kegiatan pengabdian pada masyarakat yang dilaksanakan pada MAN 18 Jakarta, Pondok Pesantren Baitul Hidayah Bandung dan SMAN 68 Jakarta telah terselenggara dan berjalan dengan baik. Hal ini terlihat dari antusiasme para siswa dan apresiasi guru untuk mengikuti workshop keuangan dan perbankan Syariah sangat tinggi, terbukti dari kehadiran para siswa untuk mengikuti kegiatan ini. Kepala sekolah, guru-guru, staf beserta para siswa di setiap sekolah menyambut antusias kegiatan pengabdian pada masyarakat berupa sosialisasi dan pengenalan keuangan dan perbankan syariah. Hal ini diharapkan dapat membantu pemerintah dalam meningkatkan tingkat indeks literasi keuangan Syariah masyarakat, sehingga ketika Indonesia mendapat bonus demografi pada tahun 2030 mendatang, industry keuangan Syariah dapat dikuasai sepenuhnya 
dan dinikmati dampaknya oleh masyarakat Indonesia.

Kendala - kendala yang dihadapi dalam pelaksanaan pengabdian masyarakat ini adalah masalah waktu pelaksanaan yang sangat terbatas. Hal ini disebabkan kondisi lalu lintas baik di Jakarta dan maupun di Bandung yang tidak menunjang kelancaran transportasi. Namun, kendala dan masalah yang terjadi dapat diselesaikan dengan baik dengan solusi menyesuaikan waktu antara pihak sekolah (mitra) yaitu MAN 18 Jakarta, pondok Pesantren Baitul Hidayah Bandung dan SMAN 68 Jakarta dengan Tim Pengabdian Masyarakat Indonesia Banking School Jakarta sehingga pelaksanaan kegiatan pengabdian masyarakat di sekolah-sekolah tersebut dapat terlaksana dengan baik.

\section{Kesimpulan}

Kegiatan pengabdian pada masyarakat workshop sosialisasi dan pengenalan keuangan dan perbankan syariah di MAN 18 Jakarta, pondok Pesantren Baitul Hidayah Bandung dan SMAN 68 Jakarta telah dilaksanakan dengan baik dan tertib. Melalui pengabdian pada masyarakat ini, diharapkan indeks literasi keuangan syariah dikalangan siswa dapat meningkat, sehingga pada akhirnya dapat berkontribusi pada pengembangan industry keuangan syariah.

\section{Daftar Pustaka}

Azwar, Saifuddin, 1995, Sikap Manusia : Teori dan Pengukurannya, Pustaka Pelajar, Yogyakarta

Bianco, Candy A., Bosco, Susan M., Roser William, 2012, Financial (IL) Literacy of College Student, The Journal of American Academy of
Business Cambridge, Vol.18, Num 1, September

Chen, Haiyang,Volpe, Ronal P., 1998, An analisys of Personal Financial Literacy Among College Students, Financial Services Review, Vol. 7 No. 2, pp. 107-128.

Engel, James F., Roger D., Blackwell, Paul W.Miniard, 1995, Perilaku Konsumen, Edisi Indonesia, Binarupa Aksara, Jakarta

Gardner, H., 1999, Intelligences Reframed: $\quad$ Multiple intelligences for the 21st century, New York: Basic Books

Huston, Sandra, J., 2010, Measuring financial literacy. Journal of Consumer Affairs Volume 44 Issue 2.

Nova, Yulia, 2011, Pengaruh Pengetahuan, Tingkat Pendidikan dan Pendapatan Terhadap Preferensi Nasabah Dalam Mengambil Keputusan Menjadi Nasabah Bank Syariah, Tesis, Universitas Indonesia

Sabri, Mohamad Fazli, Maurice MacDonald, 2010, Saving Behavior and Financial Problems Among College Students : The Role of Financial Literacy in Malaysia, Cross Cultural Communication, Vol.6 No.3, 2010, pp. 103 - 110

Tim Otoritas Jasa keuangan, 2013 Strategi Nasional Literasi Keuangan, Jakarta, Direktorat Informasi dan Edukasi OJK.

Tim Otoritas Jasa keuangan, 2013 Seri Literasi Keuangan : Perencanaan Keuangan Ibu Rumah Tangga, Jakarta, Direktorat Informasi dan Edukasi OJK 